\title{
Federal Urban Job Creation: A Systemic Analysis
}

\author{
Robert A. Zahradnik
}

Robert Zahradnik is a first-year graduate student in the master of public administration program with a concentration in state and local finance management. He is a Banneker Fellow at the Center for Washington Area Studies. Mr: Zahradnik graduated with high distinction from The Pennsylvania State University in 1992 with a bachelor of arts in mass communications and minors in history and business. Prior to graduate school, Mr. Zahradnik worked as a legal assistant for a law firm in New York City.

Many urban neighborhoods in this country are afflicted by unemployment, homelessness, poverty, and drug-related crime. Most Americans have learned to deal with these problems by simply avoiding the inner city. Unfortunately, the people living in these areas must face the problems of economic and social decline every day. For millions of urban dwellers, the financial resources needed to move out of the inner city have not materialized. Others have family and cultural ties to their communities which compel them to stay. The question to ask, then, is what can be done to improve distressed central city areas and provide some hope for the victims of urban blight.

The purpose of this article is to analyze selected federal urban policies designed to provide economic revitalization to inner cities. First, the need for urban job creation will be discussed. Second, a rationale will be provided for the involvement of the federal government in urban job creation. Third, an analytic framework will be presented which is clesigned to address the needs of urban communities. Next, this framework will be applied to current and proposed federal policies to see if the federal government is making a positive contribution in the area of urban job creation policy. Finally, the author will provide a policy recommendation.

The need for urban job creation is evidenced by the high levels of unemployment in central cities, a term used by the U.S. Bureau of the Census to mean the largest urban area within a metropolitan statistical area (MSA). ${ }^{1}$ For seventeen central cities regularly tracked by the Bureau of Labor Statistics, the 1993 unemployment rate (the most recent available for these areas) was 9.8 percent, compared to the 6.8 percent national unemployment rate for the same year. ${ }^{2}$ Central cities such as St. Louis and Detroit experienced excessive levels of unemployment during 1993, 15.8 percent and 13.7 percent, respectively. ${ }^{3}$
Even during periods of robust economic growth for the nation, such as in 1988 when the Gross Domestic Product was growing at a healthy 3.9 percent and unemployment was a modest 5.5 percent, the rate of unemployment in these same seventeen central cities still exceeded that of the nation's by an average of 2.9 percent, "The unemployment rate in St. Louis for 1988 was nearly twice as high as the nation's and the unemployment rate in Detroit was three times as high as the national rate.

Pending welfare reform is likely to widen these disparities. The leading Congressional welfare reform proposal, for example, would limit eligibility requirements and shorten the participation period for many recipients. ${ }^{6}$ Essentially, the success of this kind of welfare reform depends upon the ability of welfare recipients to find jobs and achieve self-sufficiency. If more jobs are not created, cities are likely to be burdened with increased homelessness, crime, and other problems that accompany urban poverty.

The failure of cities to attract private investment, along with the increased need for jobs as a result of welfare reform, necessitate some type of public-sector action in the area of urban job creation. Currently all levels of government-federal, state, and local-play a role in urban economic development. City governments have development departments to promote cities and attract businesses. State governments have also experimented with economic development initiatives to alleviate urban blight. Finally, the federal government has long been involved in assisting state and local governments to create jobs in central cities. Increasing fiscal pressure on urban governments requires continued support by the federal government in the area of urban job creation. Over the last twenty-five years, the fiscal capacity of cities has steadily declined, frustrating the ability of urban governments to deal with a myriad of problems. In 1969, the Advisory Commission on 
Intergovernmental Relations released a report stating:

America's central cities are faced with the necessity of spending abnormal amounts per pupil for education and abnormal amounts per capita for such functions as sanitation, law enforcement, and welfare at the same time that their tax bases are being eroded by a continuing exodus of businesses and moderate and upper income people to the suburbs. ${ }^{7}$

Since the issuance of that report, there have been increases in violent crime and drug trafficking throughout our nation's cities. ${ }^{8}$ These compelling problems of public safety further erode the budgetary capacity of cities to address urban job creation. Helen Ladd and John Yinger in their book America's Ailing Cities, which details the fiscal health of urban areas, conclude that:

powerful economic and social trends have led and will continue to lead to a deterioration in the fiscal condition of the average central city and to a large and growing fiscal disadvantage for many cities, such as those with large populations or with low and falling resident income.?

Given the budgetary stress on central city governments, state and federal assistance is necessary in the area of job creation,

\section{The failure of cities to attract private} investment, along with the increased need for jobs as a result of welfare reform, necessitate some type of public-sector action in the area of urban job creation.

State governments, however, have been faced with increasing budgetary obligations as well. The current political climate reflects a philosophy of federalism predicated on shifting many responsibilities of government to the state level. At the same time, several federal initiatives have increased the fiscal burden on state and local governments. Dennis Zimmerman, a specialist in public finance, outlined several of these provisions in a recent report on urban issues:

The highest Federal income tax marginal rate was reduced from 70 percent to 31 percent, which made the after-Federal-tax cost of State and local taxes more expensive. The ability of State and local governments to use tax-exempt bonds to finance eco- nomic development schemes for tax base expansion was restricted, and increasing numbers of expensive Federal mandates were imposed on the State and local sector. ${ }^{\text {n }}$

Congress recently acted to reduce the future burden of unfunded federal mandates, but all previous mandates must still be met. This trend of trickle-down federalism is likely to continue as states shift responsibilities to the already overburdened local level.

In sum, state and local governments lack the fiscal capacity to handle the growing complexity of urban problems in the United States. As municipal budgets are increasingly burdened by public safety and educational needs, job creation in the most distressed urban areas may not be adequately addressed. The lack of investment capital and pending changes in the welfare system demand a federal role in urban job creation policy.

\section{Analytical Framework}

This paper will proceed on the assumption that the federal government needs to play a role in formulating urban job creation policies. Several major federal programs will be analyzed for their job creation potential in distressed urban communities. The evaluation for this analysis will be based on two criteria: effectiveness and systemic applicability.

The first evaluation criterion, effectiveness, concerns the ability of a policy to create jobs for the targeted population. Although some analysts would judge a job creation policy in terms of the magnitude by which the policy improves overall regional economic performance, the definition of effectiveness this article uses will be somewhat different. This is because many policies designed to stimulate regional economic growth have historically left distressed urban areas behind. To address these structural economic problems, this article will define effectiveness as the extent to which a policy actually creates jobs at the appropriate skill level for central city residents. Finally, in order to be considered effective, a viable federal job creation policy must work regardless of the level of economic distress in a particular community.

The second criterion, systemic applicability, is based on the assumption that urban policies operate within a system of urban problems. Although systemic theory has had a long history, the concept of systemic applicability used in this article is based largely on the organic theory of community-based development articulated recently by Herbert J. Rubin. After extensive interviews with community 
activists, Rubin observed that community economic problems, such as unemployment and poverty, occur in a broad social context. Rubin asserts that an urban policy that neglects to consider interrelated socioeconomic elements will not provide a long-term solution. ${ }^{11}$

From this theoretical base, the systemic applicability criterion will be used to examine several urban development. policies for their ability to balance job creation with other critical needs. While these other elements are many, this article will limit examination to two fundamental areas: job training and housing development. Although several separate policies of the federal government currently address job training and housing, this article will be concerned with the mixture of these systemic elements within individual policies.

Job training and housing development were chosen because sustained economic improvement depends not only on job creation-the policy objective-but also on adequate job skills and affordable housing. A job creation policy without skills training could leave residents underqualified for the community job market and new jobs could go to people from outside the community, or not be filled at all. A job creation policy not linked to a housing policy could result in higher-income households moving into the area which may force out current residents or increase the percentage of their income paid for housing., ${ }^{12}$

\section{Overview of Alternatives}

The federal government has two primary tools at its disposal to provide targeted aid: tax expenditure policies and spending policies. Tax expenditures are policies whereby the government spends money through the forfeiture of tax revenue. Tax expenditures can include provisions such as tax credits intended to lower taxable income, lowered tax rates, and the elimination of certain taxes. Spending policies occur when the government provides direct funding to particular entities. The urban job creation policies to be discussed include two federal tax expenditure policies: enterprise zones and tax credits on donations to community development organizations. In addition, this article will examine two spending policies: Community Development Block Grants and community development banking.

\section{Urban Enterprise Zones}

Enterprise zone policies, in general, consist of tax incentives and deregulation to promote business development in a specified area. Since the early 1980s, enterprise zones have existed on the local and state level. Recently, a federal urban enterprise zone (UEZ) policy for job creation was designed to utilize federal tax incentives, generally considered more significant than state incentives, to spur economic growth.

The first federal government UEZ initiative to be signed into law was the Clinton administration's Empowerment Zones and Enterprise Communities (EZEC) program enacted by Congress as part of the Omnibus Budget

Reconciliation Act of 1993. ${ }^{13}$ The program established ninety-five enterprise communities divided among sixty-five urban and thirty rural areas, as well as nine empowerment zones comprised of six urban and three rural communities. The federal tax incentives established by the policy include tax exempt bonds of up to $\$ 3$ million to finance facilities for all zones. ${ }^{14}$ In addition, the empowerment zones receive a 20 percent employer-wage credit for the first $\$ 15$ thousand of zone resident wages, and an increased allowance from $\$ 10$ thousand to $\$ 20$ thousand for expensing depreciable property in the first year. ${ }^{15}$ The EZEC tax benefits are estimated to cost $\$ 2.5$ billion from fiscal year 1995 through 1999. ${ }^{16}$

The potential effectiveness of the EZEC program may first be assessed by looking at state enterprise zone policies. Marilyn Rubin, in "New Jersey Urban Enterprise Zones," summarized the available empirical evidence;

In the United States, studies of enterprise zone programs have produced mixed results, with some research yielding positive findings, and other studies negative findings, regarding the impact of enterprise zones on economic development. No study, however, has provided conclusive evidence that enterprise zones are the sole contributing factor to job growth in distressed areas. ${ }^{17}$

Truly, reviews of the effectiveness of enterprise zones have been mixed. On the positive side, a 1989 study by economic analysts Rodney Erickson and Susan Friedman concluded that:

Although EZs are no panacea for ailing areas, growth rates of gross job increases were higher than the national rate in nearly a third of the zones included in the study. ${ }^{18}$

In contrast, Patrick Grasso and Scott Crosse's review of the U.S. General Accounting Office's study of three municipalities in Maryland concluded: "This analysis provides no evidence that the Maryland enterprise zone program increased employment in the areas GAO studied," "19 


\section{State and local governments lack the fiscal capacity to bandle the growing complexity of urban problems in the United States... the federal government needs to play a role in formulating urban job creation policies.}

Other empirical research does not support the job creation potential of UEZs. Evidence suggests that large industrial firms, in varying industries and levels of technological sophistication, place relatively more importance on "quality of life" factors than "least-cost" factors in firm location decisions. ${ }^{20}$ As a result, large firms will be less responsive to government policies, such as tax abatement, and more inclined to locate in the targeted urban area after the community has been revitalized. Nevertheless, large firms are usually the only types of industry with sufficient capital to take advantage of the tax breaks offered in enterprise zones. Small business entrepreneurs, who tend to have personal ties to a geographic area and are therefore willing to locate their businesses in the community, do not have the capital to take advantage of the tax breaks.

Overall, empirical evidence concerning the effectiveness of enterprise zones does not yield definitive results. Erickson and Friedman, in their comparative study of several state enterprise zone policies, concluded that such policies are suited for areas with "genuine development potential." Erickson and Friedman argue that these areas

are characterized as having basic labor skills, public infrastructure, and transportation access that can make the areas attractive for investment with the marginal but catalytic contributions that $\mathrm{EZ}$ designation, incentives, and visibility can provide...

Alternative programs may be more appropriate in the most distressed areas. ${ }^{21}$

As a result, the effectiveness of an enterprise zone tax expenditure policy-particularly in distressed areas-is questionable.

Even in areas where enterprise zones may be appropriate, there is potential for an unintended distribution of benefits. Purdue University economist James Papke found that only 17 percent of the manufacturing jobs created in Indiana's ten zones went to zone residents. ${ }^{2 i}$ The policy also has the potential of transferring existing jobs from a community outside the zone, resulting in a "zero sum game" whereby zone residents are made better off at the expense of inb seekers elsewhere. Given these potential results outside the policy objective, effective enterprise zones may require a high level of administrative oversight to ensure that central city residents are the recipients of the benefits, ${ }^{23}$

Enterprise zones may also be disadvantageous in regard to systemic applicability. Historically, jobs created by enterprise zone policies were intended to occur indepenclent of any other governmental intrusions. As a result, enterprise zones have not tended to integrate job creation, training, and housing elements in a systemic fashion. From a free market perspective, the economic stimulus provided by tax incentives alone should lead to the optimum distribution of housing and job training in each community. As discussed earlier, however, large firms with capital are less enticed by tax incentives than by "quality of life" factors when deciding to expand operations. In addition, many entrepreneurs with less capital are not in the fiscal position to take advantage of these tax breaks. Thus, the systemic needs of an urban job creation policy are neglected by the enterprise zone approach.

\section{Community-Based Job Creation}

A second tax expenditure policy was passed as part of the Omnibus Budget Reconciliation Act of 1993 which allowed for a 5 percent tax credit on contributions to certain designated Community Development Corporations (CDC) ${ }^{24}$ The provision limited the number of qualified CDCs to twenty, twelve of which are located in urban areas. ${ }^{25}$ This provision is an indirect job creation policy because jobs are created through the economic development activities of CDCs.

Before evaluating this policy, the activities of CDCs must be clearly explained. First, CDCs assess the goals of the community and develop comprehensive strategies and programs to reach these goals. Second, CDCs serve as the central repository for development funds received from both public and private sources. Finally, $\mathrm{CDCs}$ distribute funds in the form of loans or grants for business development. ${ }^{26}$ For example, one popular distribution mechanism is the Revolving Loan Fund (RLF) which is continually replenished by loan repayments. RLFs distribute small sums of money to community businesses-amounts generally considered too small for local governments or private banks to provide. Money from RLF loans is typically used to alleviate start-up costs and cash-flow problems for small businesses. ${ }^{27}$ 


\section{Evidence suggests that large industrial firms...place relatively more importance on "quality of life" factors than "least-cost" factors in firm location decisions.}

Beyond the crucial financial role, CDCs also provide a wide array of services to insure that the needs of the community are met. For example, CDCs are involved in community-building activities such as emergency food services, job training, child care, health care, anti-drug efforts, homeowner counseling, anticrime campaigns, and youth programes. ${ }^{29}$ Herbert Rubin states that CDCs

are about creating assets within communities, assets that are visible as commercial space industrial properties, and affordable residences, and, assets owned by individuals such as job skills, education, and an increased self-worth. ${ }^{29}$

CDCs therefore play an important role in the economic development of distressed urban areas.

The effectiveness of a federal policy supporting the activities of CDCs is apparent if one looks at the success of community development organizations in creating jobs. For example, in 1991 CDCs were estimated to have created or retained ninety thousand permanent jobs in the preceding five years ${ }^{30} \mathrm{CDCs}$ headquartered directly within distressed areas tend to exert the most leverage on the problem of chronic, inner-city unemployment. In a way, such CDCs become part of their host communities, and thus part of an informal communications network essential for long-term job creation. Herbert Rubin further explains that the CDC, "through its knowledge about community members and its permanence within the neighborhood, can assure that community people are hired and trained for the specific needs of local businesses." ${ }^{31}$

CDCs operate well within the context of an urban policy system. CDC personnel perform a variety of services which apply to the systemic model including small business capital financing, technical training, and housing development. For example, Southern Dallas Development Corporation (SDDC) has successfully combined capital financing and training to create and retain over nine hundred jobs geared towards low- and moderate-income persons. The SDDC supplies direct loans to small businesses and minority businesses and provides a variety of training programs including business training, third-party technical assistance train- ing, and intensive entrepreneurial training. ${ }^{32}$

New Community Corporation in Newark, New Jersey, is an example of a CDC with extensive housing and job training services. New Community operates an employment center which has served over twenty-five hundred people per year; it made over thirteen hundred placements in $1991^{33}$ New Community has developed and manages approximately 2,700 housing units, with 1,236 units for special populations including the elderly, people with disabilities, or the formerly homeless. ${ }^{34}$

\section{Community Development Block Grant}

The primary Federal grant program for community development assistance to state and local governments is the Community Devielopment Block Grant (CDBG) program, administered by the Department of Housing and Urban Development (HUD). In 1992, the program's appropriation of $\$ 3.4$ billion represented 45 percent of the total funding for community and regional development. ${ }^{35}$ The program allots 70 percent of its funding directly to large urban communities through the CDBG Entitlement Program, and 30 percent to states for smaller urban and rural communities. ${ }^{36}$ As the Housing and Community Development Act of 1974, which established the CDBG program, states:

The primary objective of this title is the development of viable urban communities, by providing decent housing and a suitable living environment, and by expanding economic opportunities, principally for low- and moderate-income persons. ${ }^{37}$

The program annually awards grants to cities and urban counties which are entitled to the funding based on population. The amount of each grant is determined by statutory formulas using several indicators including poverty, population, housing overcrowding, age of housing, and population growth lag. ${ }^{38}$

\section{Historically, jobs created by enterprise zone policies were intended to occur independent of any other governmental intrusions. As a result, enterprise zones bave not tended to integrate job creation, training, and bousing elements in a systemic fashion.}

The Clinton administration has recently enhanced the 
$\mathrm{CDBG}$ program with the Performance Bonus pool. This pool is designed to reward some communities which have performed well in the CDBG program with additional money for economic development purposes. The projects to be funded by the Performance Bonus pool will foster community economic development in distressed areas with emphasis on job creation for low-income persons. The Clinton administration has proposed $\$ 250$ million to fund the Performance Bonus pool. ${ }^{39}$

Evaluating the effectiveness of $\mathrm{CDBG}$ is complicated by the historically low use of these funds for economic development purposes. The most recently available data indicate that only 11 percent of the Entitlement Program funds in 1990 were used for economic development ( $\$ 290 \mathrm{mil}-$ lion of the total $\$ 2.3$ billion). ${ }^{10}$ The proposed $\$ 250$ million Performance Bonus pool is intended to improve the funding level for economic development activities.

The primary economic development activities funded by the CDBG Entitlement Program include direct financial aid to for-profit businesses and assistance to for-profit businesses for land acquisition and infrastructure development. ${ }^{.1}$ Through these activities the CDBG program has been effective in stimulating job creation in communities throughout the country despite changes in the administration of the program. ${ }^{12}$

These administrative changes have concerned the targeting of funds to low-income residents, a strategy which, according to Michael Rich in his book Federal Policymaking and the Poor, has been subject to different interpretations by different administrations. ${ }^{43}$ Under the Ford administration, for example, HUD interpreted the social targeting objectives loosely. ${ }^{\text {th }}$ In contrast, under President Carter, "HUD issued a directive to its field offices in April 1977 outlining the department's commitment to the statutory objectives concerning the issues of principal benefit to low- and moderate-income persons. ${ }^{145}$ The flexibility of the blockgrant program in allowing grantees to meet the systemic needs of their communities has helped the program to remain effective in job creation despite these administrative changes..$^{46}$

The CDBG program also fits well within Rubin's systemic framework because the funds may be utilized for not only job creation, but also job training and housing development. In the area of job training, the program includes a Technical Assistance Program which provides aid in the form of group training, written materials, on-site assistance, and developing and negotiating projects. ${ }^{77}$ For example, the city of Flint, Michigan, in 1993 received over $\$ 197,000$ in CDBG technical assistance funding to pay for an entrepreneurial training program focusing on self-employment and small business ownership for low-income neighborhood residents. ${ }^{49}$

Welfare programs based on serving
individuals bave not revitalized urban
communities; in fact, these strategies bave
often bastened the demise of these areas
by belping some people move out while
leaving the rest bebind.

Overall, the flexibility of the block grant allows jurisdictions to meet each community's most pressing need, which is usually housing. The systemic element of the policy is only truly achieved if each jurisdiction develops a comprehensive plan to use CDBG funds, along with revenue from local sources, to provide adequate housing, job creation, and job training for low income individuals.

\section{Community Banking}

At the end of 1994, Congress passed the Community Development Banking and Financial Institutions Act of 1994, which established a national fund for community development banking. The fund is designed to provide assistance to established community development financial institutions (CDFIs) that are likely to succeed in providing needed investment in areas of economic distress. ${ }^{49}$ The fund will provide technical assistance, through grants or by contracting with organizations that possess expertise in community development finance, as well as direct financial assistance through equity investment, deposits, credit urion shares, loans, and other monetary awards. The legislation limits financial assistance to $\$ 5$ million for each institution. All fund assistance must be matched with money from other sources on a dollar-for-dollar basis. ${ }^{50}$ The legislation authorizes $\$ 382$ billion to be spent over four years. ${ }^{51}$

The effectiveness of the Community Banking Act in job creation is based on the ability of the various CDFIs to finance business development. There are four primary types of CDFIs: community development banks, community development credit unions, community development loan funds, and community development corporations. ${ }^{52}$ Each of these has played an important role in job creation in distresed usban areas by providing the capital necessary for $u$ business development. For example, the 
three development banks in the U.S. have financed over $\$ 40$ million in loans to approximately one thousand small businesses. ${ }^{53}$ The forty-one loan funds across the nation have made more than $\$ 88$ million in loans and attracted more than $\$ 643$ million in additional capital, resulting in thirty-seven hundred jobs for primarily low income people. ${ }^{54} \mathrm{~A}$ Congressional report on the legislation concluded:

Evidence presented before the Committee indicates that community development financial institutions have proven themselves effective in filling gaps and developing comprehensive revitalization strategies. ${ }^{55}$

The Community Banking Act also clearly indicates a high level of systemic applicability. The statute states that financial assistance provided by the fund may be used by CDFIs to invest in job creation and housing for lowincome people. The act also includes a training provision which allows the fund to sponsor a training program to educate CDFI personnel on issues related to community development finance. ${ }^{36}$ Although this provision does not constitute "job training," it does enhance the systemic applicability of the program by ensuring that CDFIs are equipped to meet the complex needs of residents.

\section{Policy Recommendation}

Based on the discussion of the policies and the application of the evaluation criteria, a three-pronged policy recommendation emerges:

1. sustained funding of the CDBG program with additional economic development funding through the implementation of the Performance Bonus pool;

2. expansion of the tax credit to support community development organizations;

3. maintenance of the fund for community development banking.

In addition, the tax expenditure provisions of EZEC program should be rescinded, and the five-year savings of $\$ 2.5$ billion used to pay for these recommendations.

First, the CDBG is an effective job creation program with a high level of systemic applicability. The program's strength is its flexibility which allows the grantees to meet the systemic needs of their community through a comprehensive development strategy. The Performance Bonus pool provides an incentive for grant recipients to strive towards excellence in community economic development. At the same time, Bonus pool funds are earmarked for economic development and job creation, which have often been sac- iificed to mex: more urgent housing needs.

The tax credit on donations to CDCs provides a public-sector incentive for private citizens to donate to these positive instruments of change. The current policy of a 5 percent tax credit for twenty eligible CDCs should be expanded as follows: the percentage rate of the tax credit should be increased to provide a stronger incentive to donors, and the number of eligible $\mathrm{CDCs}$ should be increased to include additional worthy organizations. These changes will enhance the overall effect of this policy.

The fund for community development banking established by the Community Development Banking and Financial Institutions Act of 1994 is a critical element in urban job creation because it provides the necessary capital to finance business development in distressed urban areas. The fund is systemic in nature because, like the $\mathrm{CDBG}$ program, the flexibility exists to use funding for both economic development and housing. The authorizing legislation also allows for technical training in the area of business financing and housing development.

The federal community-based job creation policies advocated in this article recognize the need for the public, private, and nonprofit sectors to work together at the local level to improve the welfare of community residents. The CDBG program has been a source of greatly needed funds for communities across the nation. In many cases, CDCs are utilized in the implementation of projects funded by block grants and other sources. ${ }^{57}$ The tax credit for donations to $\mathrm{CDCs}$ helps keep these organizations viable while rewarding private-sector contributors for their important role in urban job creation. Finally, the Community Banking Act provides investment capital to community development financial institutions, including $\mathrm{CDCs}$, to stimulate economic development.

\section{Conclusion and Outlook}

In sum, the policies discussed in this paper represent an antipoverty strategy that aims to improve central city communities rather than serve individuals separately from their communities or wait for economic growth to improve each city's lot. Welfare programs based on serving individuals have not revitalized urban communities; in fact, these strategies have often hastened the demise of these areas by helping some people move out while leaving the rest behind. Distressed urban communities tend not to benefit from national or regional economic growth due in large part to the lack of investment capital for small business 
entrepreneurs and "quality of life" factors sought by expanding larger firms.

Current federal budgetary constraints do not allow for the implementation of sweeping new domestic policies to solve urban problems. As a result, the policies proposed in this article are relatively modest. Perhaps in the future, the budgetary situation will improve and more significant urban policies may be implemented.

Regardless of the state of the economy, urban policymakers should be concerned with both effectiveness and the systemic elements of job creation, job training, and housing discussed in this paper. The coordination of these elements is a vital aspect of any successful job creation policy. $\star$

\section{Notes}

tI would first like to thank my article editor; Jevera Temsky, for her patience and stylistic improvements, and my associate editor, Katie Donahue, for her diligent research assistance. My thanks also goes to Philip Bransford for his acute attention to detail and his unswerving dedication to Policy Perspectives. I would also like to thank Professor Jill Kasle for providing editorial guidance and the motivation to persevere. On a personal note, I owe thanks to my parents for their unconditional support of all of my endeavm ors. Finally, I owe the greatest thanks to Jennifer who has supported me throughout the writing of this article.

'Bureau of the Census, Poverty in the United States: 1991, Series P-60, No. 181 (Washington, D.C., 1991), A-1.

${ }^{2}$ Department of Labor; Bureau of Labor Statistics, Geographic Profile of Employment and Unemployment, 1993 (Washington, D.C.: Government Printing Office, 1994), 107-111; Council of Economic Advisors, Economic Report of the President, 1995 (Washington D.C.: Government Printing Office, 1995), 320.

${ }^{3}$ Department of Labor, Geographic Profile, 1993, 108, 110.

${ }^{4}$ Council of Economic Advisors, 277, 320; Department of Labor, Bureau of Labor Statistics, Geograpbic Profle of Employment and Unemployment, 1988 (Washington, D.C.: Government Printing Office, 1989), 103-108.

'Department of Labor, Geographic Profile, 1988, 104, 107.

${ }^{6}$ Personal Responsibility Act of 1995, 104th Cong., 1st sess., H,R. 1214.

${ }^{7}$ Advisory Commission on Intergovernmental Relations, Urban America and the Federal System M-47 (Washington, D.C.,: Government Printing Office, 1969), 2.

${ }^{8}$ Department of Justice, Federal Bureau of Investigation, Crime in the United States, 1993: Uniform Crime Reports (Washington, D.C.: Government Printing Office, 1994), 12; Department of Justice, National Institute of Justice, Identifying and Responding to New Forms of Drug Abuse: Lessons Learned from "Crack" and "Ice" (Washington, D.C.: Department of Justice, 1993), 1-6.

'Helen F. Ladd and John Yinger, America's Ailing Cities. (Baltimore: The Johns Hopkins University Press, 1989), 297.

${ }^{10}$ Dennis Zimmerman, "Intergovernmental Fiscal Relations," The
Cities: Problems and Legislative Proposals. (Washington, DC: Congressional Research Service, Library of Congress, 1992), CRS6.

"Herbert J. Rubin, "There Aren't Going to Be Any Bakeries Here If There Is No Money to Afford Jellyrolls: The Organic Theory of Community Based Development," Social Problems 41, no. 3 (August 1994); 401-424.

${ }^{12}$ Marshall Kaplan, "American Neighbourhood Policies; Mixed Results and Uneven Evaluations," in Neighbourbood Regeneration: An International Evaluation (London and New York: Mansell Publishing, 1991), 37.

${ }^{13}$ Public Law 66, 103rd Cong., 1st sess. (10 August 1993), Omnibus Budget Reconciliation Act of 1993, 543-556.

${ }^{14}$ Ibid., 548.

${ }^{15}$ Ibid., 549, 552.

16Joint Committee on Taxation, Estimates of Federal Tax Expenditures for Fiscal Year 1995-1999, report prepared for the Committee on Ways and Meands and the Committee on Finance, 103rd Cong., 2nd sess., 1994, Joint Committee Print, 16.

${ }^{17}$ Marilyn Rubin, "Urban Enterprise Zones: Do they work? Evidence from New Jersey," Public Budgeting and Finance 10 (Winter 1990): 6.

${ }^{1 " R o d n e y ~ A . ~ E r i c k s o n ~ a n d ~ S u s a n ~ W . ~ F r i e d m a n, ~ " C o m p a r a t i v e ~}$ Dimensions of State Enterprise Zone Policies," in Enterprise Zones: New Directions in Economic Development (Newbury Park, CA: Sage Publications, 1991), 171.

${ }^{19}$ Patrick Grasso and Scott B. Crosse, "Enterprise Zones: Maryland Case Study," in Enterprise Zones: New Directions in Economic Development (Newbury, CA: Sage Publications, 1991), 133.

${ }^{20}$ Stuart L. Hart, Daniel R. Denison, and Douglas A. Henderson, "A Contingency Approach to Firm Location: The Influence of Industrial Sector and Level of Technology," Policy Studies Joumal 17, no. 3 (Spring 1989): 617.

${ }^{21}$ Erickson and Friedman, 175.

${ }^{22}$ James A. Papke, Monitoring Indiana Enterprise Zones: Analysis and Appraisal (West Lafayette, Ind.: Purdue University, October 
1989), xiii.

${ }^{23}$ Economic policy analysts Richard C. Elling and Ann Workman Sheldon, in a study of state enterprise zone programs, concluded that: "There is, of course, more than a little irony in the fact that the success of an economic development strategy long associated with political conservatives may ultimately depend so heavily on the efforts of bureaucrats for its success." Richard C. Elling and Ann Workman Sheldon, "Determinants of Enterprise Zone Success: A Four State Perspective," in Enterprise Zones (Newbury Park, CA: Sage Publications, 1991), 152.

${ }^{24}$ Public Iaw 66, 556-8.

2tibid., 557.

${ }^{2}$ National Congress for Community Economic Development, Changing the Odds: The Achievements of Community-based Economic Development Conporations (Washington, D.C.: National Congress for Community Economic Development, 1991), 7, 8, 6 .

${ }^{27}$ Herbert J. Rubin, "Understanding the Ethos of Community-Based Development: Ethnographic Description for Public Administrators, Public Administration Review 53, no. 5 (1993): 433.

${ }^{2}$ National Congress For Community Economic Development, 7.

${ }^{29}$ Rubin, There Aren't Going, 419.

${ }^{30}$ National Congress for Community Economic Development, 2.

"Rubin, Understanding the Ethos, 433.

37The Department of Housing and Urban Development, Office of Community Planning and Development, Communities that Work: $C D B G=$ Jobs (Washington, D.C.: 1994), 87, 89, 90.

${ }^{33}$ Mercer L. Sullivan, More Than Housing: How Community Development Conporations Go About Changing Lives and Neigbborboods (New York, NY: Community Development Research Center, Graduate School of Management and Urban Policy, New School for Social Research, 1993), 85.

${ }^{3}$ Ibicl, 23.

"Eugene Boyd, "Community Development," in The Cities: Problems and Legislative Proposals. (Washington, D.C.: Congressional Research Service, Library of Congress, 1992), CRS14 .

${ }^{36}$ U.S. Department of Housing and Urban Development, Assistant Secretary for Community Planning and Development, Annual Report to Congress on the Community Development Block Grant Program: 1993 (Washington, D.C., 1993), 1-1.

"Public Law 383, 93rd Cong., 2nd sess., (22 August 1974), Housing and Community Development Act of 1974, 714 .
HUD, Annual Report, 1-1.

39Department of Housing and Urban Development, HIDD Reinvention: From Blueprint to Action (Washington, D.C.: 1995), 18.

*HUD, Annual Report, 1-1.2.

"Ibid, 1-14.

${ }^{2}$ HUD, Communities That Work.

${ }^{4}$ Michael J. Rich, Federal Policymaking and the Poor (Princeton, N.J.: Princeton University Press, 1993), 30-56.

"Ibid., 35.

${ }^{4}$ Ibid., 36.

"Despite a long-standing concern over the effectiveness of block grants (on the grounds that local governments' use of block grant funding frequently extends beyond original policy objectives), history suggests that the CDBG program has performed relatively well over the long term. As Rich states: "By many counts, CDBG is a popular and effective program. Unlike many previous HUD programs, CDBG has been relatively free of scandal and charges of waste, fraud, and misuse of funds. Its longevity alone attests to its success." Rich then argues the primary concern regarding localities' use of the funds is the targeting of benefits to low and moderate income people. Without unduly limiting the freedom block grants afford localities, the federal government should nevertheless take an active role in ensuring that policy objectives are met through field office evaluation and oversight. [1bid., 348].

"HUD, Annual Report, 6-3.

${ }^{4}$ HUD, Communities that Work, 46-7.

"Public Law 325, 103rd Cong., 2nd sess. (23 September 1994), Community Development Banking and Financial Institutionts Act, 2163.

silbid, , 2172-2174.

sIIbid., 2189

${ }^{5}$ Senate Committee on Banking, Housing, Urban Affairs Committee, Riegle Community Development and Regulatory Improvement Act of 1994, 103rd Cong., 1st sess., 1993, S. Rept. 103-169, 10.

"3bid.

9Ibid., 11.

"5ibid., 10.

sublic Law 325, 2176.

"HUD, Communities that Work. 


\section{Bibliography}

Boyd, Eugene. "Community Development," In The Cities: Problems and Legislative Proposals. Washington, D.C.: Congressional Research Service, Library of Congress, 1992.

Elling, Richard C,, and Ann Workman Sheldon. "Determinants of Enterprise Zone Success: A Four State Perspective," In Enterprise Zones: New Directions in Economic Development. Newbury Park, Calif.: Sage Publications, 1991.

Erickson, Rodney A., and Susan W. Friedman. "Comparative Dimensions of State Enterprise Zone Policies," In Enterprise Zones: New Directions in Economic Development. Newbury Park, Calif: Sage Publications, 1991.

Grasso, Patrick G., and Scott B. Crosse. "Enterprise Zones: Maryland Case Study," In Enterprise Zones: New Directions in Economic Development. Newbury Park, Calif.: Sage Publications, 1991.

Hart, Stuart L., Daniel R. Denison, and Douglas A. Henderson. "A Contingency Approach to Firm Location: The Influence of Industrial Sector and Level of Technology." Policy Studies Journal 17, no. 3 (spring 1989): 615-625.

Kaplan, Marshall. "American Neighbourhood Policies: Mixed Results and Uneven Evaluations," In Neigbbourbood Regeneration: An International Evaluation. London and New York: Mansell Publishing Limited, 1991.

Ladd, Helen F., and John Yinger. America's Ailing Cities: Fiscal Health and the Design of Urban Policy. Baltimore: The Johns Hopkins University Press, 1989.

National Congress for Community Economic Development. Changing the Odds: The Acbievements of Community-based Development Corporations. Washington, D.C.: National Congress for Community Economic Development, 1991.

Papke, James A. Monitoring Indiana Enterprise Zones: Analysis and Appraisal. West Lafayette, Ind.: Purdue University, 1989.

Rich, Michael J. Federal Policymaking and the Poor. Princeton, N.J.: Princeton University Press, 1993.

Rubin, Herbert J. "There Aren't Going to Be Any Bakeries Here If There Is No Money to Afford Jellyrolls: The Organic Theory of Community Based Development," Social Problems 41, no. 3 (August 1994): 401-424.

"Understanding the Ethos of Community-Based Development: Ethnographic Descriptions for Public Administrators," Public Administration Review 53, no. 5 (September- October, 1993): 428-437.
Rubin, Marilyn. "Urban Enterprise Zones: Do They Work? Evidence From New Jersey," Public Budgeting and Finance 10 (winter 1990): 3-17.

Sullivan, Mercer L. More Than Housing: How Community Development Corporations Go About Changing Lives and Neigbborboods. New York, N.Y.: Graduate School of Management and Urban Policy, New School for Social Research, 1993.

U.S. Advisory Commission on Intergovernmental Relations. Urban America and the Federal System. M-47. Washington, D.C.: Government Printing Office, 1969.

U.S. Congress. Joint Committee on Taxation. Estimates of Federal Tax Expenditures for Fiscal Years 1995-1999. Report prepared for the Committee on Ways and Means and the Committee on Finance, 103rd Cong., 2d sess., 1994, Joint Committee Print.

U.S. Council of Economic Advisors. Economic Report of the President, 1995. Washington, D.C.: Government Printing Office, 1995.

U.S. Department of Commerce. Bureau of the Census. Poverty in the United States: 1991. Series P-60, no. 181. Washington, D.C.: Government Printing Office, 1992.

U.S. Department of Housing and Urban Development. HUD Reinvention: From Blueprint to Action. Washington, D.C., 1995.

- Assistant Secretary for Community Planning and Development. Annual Report to Congress on the Community Block Grant Program: 1993. Washington, D.C., 1993.

Office of Community Planning and Development. Communities that Work: CDBG=Jobs. Washington, D.C., 1994.

U.S. Department of Justice. Federal Bureau of Investigation. Crime in the United States, 1992: Uniform Crime Reports. Washington, D.C.: Government Printing Office, 1994.

. National Institute of Justice. Identifying and Responding to New Forms of Drug Abuse: Lessons Learned from "Crack" and "Ice." Washington, D.C.: Department of Justice, 1993.

U.S. Department of Labor. Bureau of Labor Statistics. Geographic Profile of Employment and Unemployment, 1988. Washington, D.C.: Government Printing Office, 1989.

Geographic Profile of Employment and Unemployment, 1993. Washington, D.C.: Government Printing Office, 1994 . *

U.S. Public Law 383. 93d Cong., 2d sess., 22 August 1974. Housing and Community Development Act of 1974. 
U.S. Public Law 66. 103d Cong., 1st sess., 10 August 1993. Omnibus Budget Reconciliation Act of 1993.

U.S. Public Law 325. 103d Cong., 2d sess., 23 September 1994. Community Development Banking and Financial Institutions Act of 1994.
U.S. Senate. Committee on Banking, Housing, and Urban Affairs. Riegle Community Development and Regulatory Improvement Act of 1994. 103d Cong., 1st sess., 1993, S. Report 169.

Zimmerman, Dennis. "Intergovernmental Fiscal Relations," In The Cities: Problems and Legislative Proposals. Washington, D.C.: Congressional Research Service, Library of Congress, 1992. 